\title{
Comparison of Nitric Oxide Production in Response to Carbachol Between Macrovascular and Microvascular Cardiac Endothelial Cells
}

\author{
Takehiko Miyashita, MD; Yasuchika Takeishi, MD; Hiroki Takahashi, MD; \\ Takuya Miyamoto, MD; Satoshi Fujii, $\mathrm{PhD} *$; Tetsuhiko Yoshimura, $\mathrm{PhD}$ *; \\ Hitonobu Tomoike, MD**; Shuichi Kato, MD ${ }^{\dagger}$; Isao Kubota, MD
}

\begin{abstract}
Cardiac microvascular endothelial cells (EC) play an important role in the physiological regulation of coronary blood flow, but their function has not been rigorously examined, because suitable in vitro models have not been available. Cardiac macrovascular and microvascular EC were isolated and cultured from 14-16-week-old Sprague-Dawley rats to examine the pharmacological responses of carbachol-induced nitric oxide (NO) production using a Griess method. Carbachol-induced NO production was only detected in cardiac macrovascular EC, which suggests that endothelial production of NO differs between macrovascular and microvascular EC. Next, cardiac microvascular EC was treated with either vehicle, angiotensin-converting enzyme (ACE) inhibitor

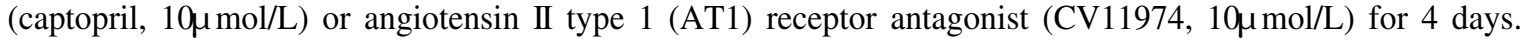
Carbachol-induced NO production was improved by captopril $(136 \pm 45 \mathrm{nmol}, \mathrm{p}<0.01$ vs vehicle) and CV11974 $(146 \pm 30 \mathrm{nmol}, \mathrm{p}<0.01 \mathrm{vs}$ vehicle). Angiotensin II concentration in the culture medium and protein expressions of endothelial nitric oxide synthase and AT1 receptor in the EC were similar among the 3 groups. Interestingly, the level of muscarinic subtype 3 (M3) receptor was significantly increased in the EC treated with captopril (214\%, $\mathrm{p}<0.01)$ and CV11974 $(296 \%, \mathrm{p}<0.01)$. When cardiac microvascular EC were treated with neomycin (non-selective phospholipase $\mathrm{C}$ inhibitor), carbachol-induced NO production was also improved $(146 \pm 35 \mathrm{nmol}, \mathrm{p}<0.01$, neomycin $1 \mathrm{mmol} / \mathrm{L})$ together with increased expression of $\mathrm{M}_{3}$ receptor $(\mathrm{p}<0.01)$. These data suggest that the upregulation of the $\mathrm{M}_{3}$ receptor by captopril or CV11974 occurs via a phospholipase C-dependent pathway. Cardiac microvascular EC also produced NO constitutively, as did the macrovascular EC, but carbachol-induced NO production was decreased. The present data suggest that the upregulation of the $\mathrm{M}_{3}$ receptor by the ACE inhibitor and AT1 receptor antagonist is a new beneficial effect of these drugs on microvascular endothelial function. (Circ J 2002; 66: 511-515)
\end{abstract}

Key Words: ACE inhibitor; AT1 receptor antagonist; Endothelium; Muscarinic receptor; Nitric oxide

$\mathbf{I}$ is now established that the vascular endothelium plays a pivotal role in the regulation of blood vessel tone through the release of chemical mediators such as nitric oxide (NO)! Because endothelium-dependent NOmediated vasodilation can be assessed by acetylcholine (ACh) or other muscarinic receptor agonists, a number of studies have used regional infusion of $\mathrm{ACh}$ and examined the resultant vasodilatation, 2,3 On the assumption that a diminished vasodilator response to ACh reflects endothelial dysfunction, evidence for an impaired endotheliumdependent vasodilator response has been found in the microcirculation of the myocardium, $4 \mathrm{leg}^{5}$ and forearm.,7 This endothelium-derived NO is not only a potent vasodilator but also an inhibitor of platelet aggregation, smooth muscle cell proliferation, monocyte adhesion and adhesion

(Received August 20, 2001; revised manuscript received January 7, 2002; accepted January 24, 2002)

First Department of Internal Medicine, Yamagata University School of Medicine, *The Institute for Life Support Technology, Yamagata Technopolis Foundation, Yamagata, **National Cardiovascular Center, Suita and Public Okitama General Hospital, Yamagata, Japan Mailing address: Takehiko Miyashita, MD, The First Department of Internal Medicine, Yamagata University School of Medicine, 2-2-2 Iida-Nishi, Yamagata 990-9585, Japan. E-mail: tmiyasit@med.id. yamagata-u.ac.jp molecule expression. Abnormalities in NO production have been demonstrated in various pathological states such as atherosclerosis, hypertension, hypercholesterolemia, ${ }^{10}$ and heart failure!1 However, the detailed mechanism of impaired endothelium-derived NO production is still unclear.

The endothelium has a significantly heterogeneous structure and function among organs, and there are differences between macrovascular and microvascular endothelium cells (EC) $!^{12-14}$ A number of studies have shown that cardiac microvascular EC play important roles in physiological and pathological conditions such as hypertrophy, ischemia, and collateral development ${ }^{15}$ In addition, endothelial dysfunction associated with hypertension and diabetes mellitus primarily occurs in cardiac microvessels. However, cardiac microvascular endothelial function has not been rigorously examined because suitable in vitro models are not available.

The purpose of this study was to examine the function of cardiac macrovascular and microvascular EC isolated from adult rat hearts.

\section{Methods}

Isolation and Culture of Adult Rat Cardiac

Macrovascular and Microvascular EC 12

Male Sprague-Dawley rats (14-16-week-old) were anes- 
thetized with sodium pentobarbital $(60 \mathrm{mg} / \mathrm{kg}$ ip), and the hearts were excised and placed in Dulbecco's modified Eagle's medium (DMEM, Gibco BRL, Rockville, MD, USA). The animals were handled according to the animal welfare regulations of Yamagata University, and the study protocol was approved by the Animal Subjects Committee of Yamagata University.

The hearts were immediately cannulated and retrogradely perfused with DMEM for $5 \mathrm{~min}$ through the ascending aorta to remove blood cells! ${ }^{2}$ After removal of connective tissue, the atria, right ventricle and all valvular tissues, the remaining left ventricular tissue was opened by an incision along the septal wall and washed with DMEM. The outer one-quarter of the left ventricular free wall (as macrovessels or conduit vessels) and the remaining heart tissue (as microvessels or resistant vessels) were separately minced finely in $0.2 \%$ collagenase in Hank's balanced salt solution (HBSS) and incubated for $25 \mathrm{~min}$ at $37^{\circ} \mathrm{C}$ in a shaking water bath. Trypsin $(0.02 \%)$ was added, and the ventricular tissue was sheared 10 times in a $10-\mathrm{ml}$ pipette and incubated for another $25 \mathrm{~min}$. Dissociated cells were washed with HBSS and centrifuged at $1,200 \times \mathrm{G}$ for $5 \mathrm{~min}$. Cells were resuspended in DMEM supplemented with $20 \%$ fetal bovine serum (Gibco BRL) and antibiotics (penicillin 100 IU/ml and streptomycin $100 \mathrm{mg} / \mathrm{ml}$; Sigma Chemical Co, St Louis, MO, USA) and plated on 12-well or 100-mm culture plates.

In the preliminary study, after isolation and plating on culture plates for 4 days, confluent primary isolates were incubated with $10 \mu \mathrm{g} / \mathrm{ml}$ of fluorescence-conjugated acetylated low density lipoprotein (LDL) labeled with 1,1'-dioctadecyl-3,3,3',3'-tetramethylindocarbocyanine perchlorate (DiI-Ac-LDL) (Biomedical Technologies, Stoughton, MA, USA) in DMEM with $20 \%$ fetal bovine serum overnight. Differential uptake of fluorescently labeled Ac-LDL on fluorescence microscopy indicated that the primary isolates of EC were quite homogeneous (data not shown).

After isolation and plating on culture plates, pre-confluent cardiac microvascular EC were incubated with vehicle (control), $10 \mu \mathrm{mol} / \mathrm{L}$ captopril (Sigma Chemical Co), 10 mmol/L CV11974 (Takeda Chemical Industries Ltd, Osaka, Japan) or $100 \mu \mathrm{mol} / \mathrm{L}$ neomycin (Sigma Chemical Co) in $10 \% \mathrm{CO}_{2}$ at $37^{\circ} \mathrm{C}$ for 4 days. Then cells were washed with $\mathrm{Ca}^{2+} 1.0 \mathrm{mmol} / \mathrm{L}$ Tyrode twice, and stimulated by 10 $\mu \mathrm{mol} / \mathrm{L}$ carbachol for $1 \mathrm{~h}$. NO in the supernatants was meas-

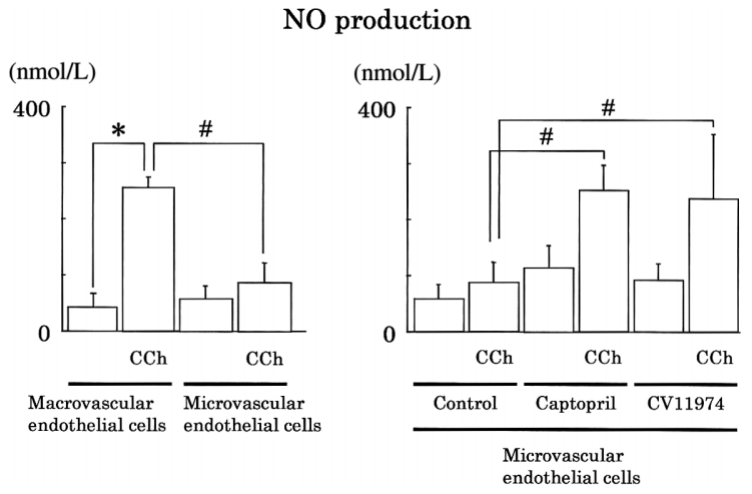

Fig 1. Comparison of NO production in response to carbachol stimulation in cardiac macrovascular and microvascular endothelial cells. In cardiac microvascular endothelial cells, treatment with captopril and CV11974 increased NO production by carbachol. Data are mean \pm SD from 8 separate experiments. ${ }^{*} \mathrm{p}<0.01$ vs basal (without carbachol) and ${ }^{\#} \mathrm{p}<0.01$ vs control (+ carbachol). CCh, carbachol. ured by the Griess method. In the present study, we also examined the muscarinic stimulation in cardiac macrovascular EC as a control in an identical manner to the microvascular EC.

\section{Determination of $\mathrm{NOx}\left(\mathrm{NO}_{2}{ }^{-} / \mathrm{NO}_{3}{ }^{-}\right)$}

The cells were plated onto 12 -well plates for 4 days, and washed with $\mathrm{Ca}^{2+} 1.0 \mathrm{mmol} / \mathrm{L}$ Tyrode buffer containing (mmol/L) $140 \mathrm{NaCl}, 5.4 \mathrm{KCl}, 1.0 \mathrm{MgCl}_{2}, 1.0 \mathrm{Na}_{2} \mathrm{HPO}_{4}, 10$ glucose, 5.0 Hepes, gassed with $10 \% \mathrm{CO}_{2}$, adjusted to $\mathrm{pH}$ 7.3 , at $37^{\circ} \mathrm{C}$ twice, and then stimulated by $10 \mu \mathrm{mol} / \mathrm{L}$ carbachol (Sigma Chemical Co) for $1 \mathrm{~h}$. NO production by carbachol was not dose-dependent over $10 \mu \mathrm{mol} / \mathrm{L}$ concentration (data not shown). The supernatants were used for NOx measurement. They were applied to a copper-coated cadmium reduction column, and NOx was determined by the Griess method with the use of an autoanalyzer (ENO10, Eicom Corp, Kyoto, Japan) ${ }^{16}$

\section{Western Blotting}

When cells were $95 \%$ confluent, they were harvested by aspirating the medium and washing with ice-cold phosphate buffered saline, and were lysed by the addition of 0.5 $\mathrm{ml}$ of ice-cold lysis buffer containing (mmol/L) $\mathrm{NaCl} 50.0$, $\mathrm{NaF}$ 100.0, Tris- $\mathrm{HCl} 25.0$, (\%) sodium deoxycholate 0.5 , NP-40 2.0, sodium dodecyl sulfate (SDS) 0.2 and sodium orthovanadate $200 \mu \mathrm{mol} / \mathrm{L}$ at $\mathrm{pH} 7.4$, along with $10 \mu \mathrm{g} / \mathrm{ml}$ leupeptin, $10 \mu \mathrm{g} / \mathrm{ml}$ aprotinin and $100 \mu \mathrm{g} / \mathrm{ml}$ phenylmethylsulfonyl fluoride. The cell lysates were then placed on ice for $30 \mathrm{~min}$, and centrifuged at $14,000 \times \mathrm{G}$ at $4^{\circ} \mathrm{C}$ for $15 \mathrm{~min}$. Supernatants were either used immediately or stored at $-80^{\circ} \mathrm{C}$. Protein concentrations were determined using a bicinchoninic acid protein assay kit from Pierce. Equal amounts $(40 \mu \mathrm{g})$ were subjected to electrophoresis on a $10 \%$ SDS-polyacrylamide gel and transferred to polyvinylidene fluoride membrane (Hybond P, Amersham Pharmacia Biotech, Inc, Piscataway, NJ, USA) as previously reported ${ }^{17,18}$ The membrane was blocked with $5 \%$ dried-milk in TNT solution containing $25 \mathrm{mmol} / \mathrm{L}$ Tris- $\mathrm{HCl}, 125 \mathrm{mmol} / \mathrm{L} \mathrm{NaCl}$, $0.2 \%$ Tween 20 at $4^{\circ} \mathrm{C}$ overnight and incubated with primary antibodies specific to endothelial nitric oxide synthase (eNOS) ${ }^{19}$ muscarinic subtype $3\left(\mathrm{M}_{3}\right)$ receptor and AT1 receptor ${ }^{20}$ (Santa Cruz Biotechnology, Santa Cruz, $\mathrm{CA}, \mathrm{USA}$ ) for $2 \mathrm{~h}$ at room temperature. After washing, the membrane was then incubated with horseradish peroxidase-conjugated anti-rabbit or anti-goat IgG secondary antibody (Santa Cruz Biotechnology, Inc) for $1 \mathrm{~h}$ at room temperature. Immunoreactive bands were visualized by

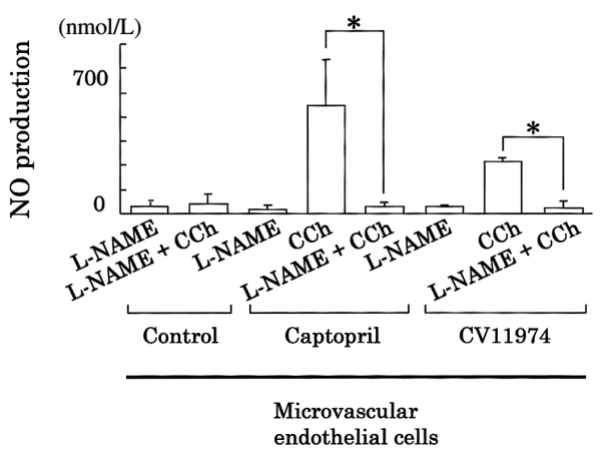

Fig 2. Effects of L-NAME on carbachol-induced NO production. Data are mean \pm SD from 4 separate experiments. *p $<0.01$. L-NAME, $\mathrm{NG}^{\mathrm{G}}$-nitro-L-arginine methyl ester. 


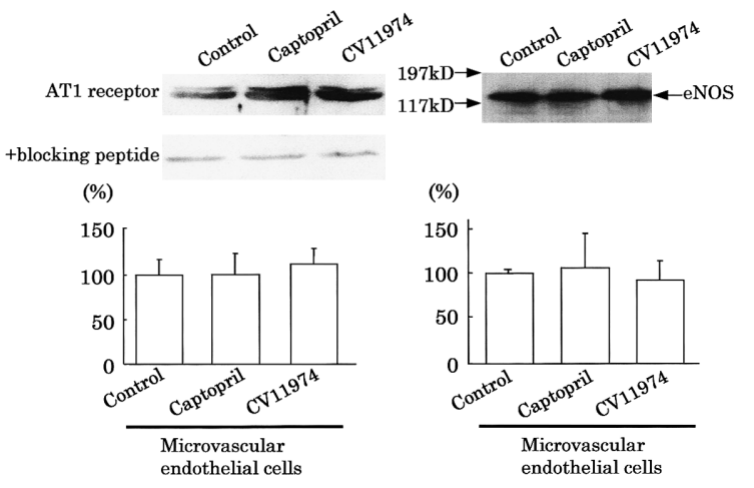

Fig 3. Protein levels of AT1 receptor (Left panel) and eNOS (Right panel) in cardiac microvascular endothelial cells. Data are mean \pm SD from 4 separate experiments.

the enhanced chemiluminescent detection method (ECL, Amersham Pharmacia Biotech, Inc) and quantified by a densitometer with an imaging system.

\section{Statistical Analysis}

Data are expressed as mean \pm SD. Statistical analysis was performed by one-way ANOVA followed by Scheffé's test. A value of $\mathrm{p}<0.05$ was taken as significant.

\section{Results}

\section{Effects of ACE Inhibitor and AT1 Receptor Antagonist on NO Production by Cardiac Microvascular EC}

We found that cardiac microvascular and macrovascular EC produced $\mathrm{NO}$ in the basal condition to a similar degree $(57 \pm 25 \mathrm{nmol}$ vs $46 \pm 18 \mathrm{nmol}$, Fig 1$)$. However, carbacholinduced NO production was significantly decreased in the microvascular EC compared with the macrovascular EC $(28 \pm 12 \mathrm{nmol}$ vs $197 \pm 23 \mathrm{nmol}, \mathrm{p}<0.01$, Fig 1$)$, which suggests that, in contrast to the macrovascular EC, the microvascular EC lack the capacity to generate NO in response to muscarinic stimulation. Interestingly, $\mathrm{NO}$ production in the microvascular EC was improved by captopril $(136 \pm 45$ nmol, $\mathrm{p}<0.01$ vs vehicle) and CV11974 $(146 \pm 30 \mathrm{nmol}$, $\mathrm{p}<0.01$ vs vehicle) to the same level as the cardiac macrovascular EC. In contrast to the microvascular EC, NO production in the macrovascular EC was unchanged by either captopril $(166 \pm 32 \mathrm{nmol})$ or CV11974 $(160 \pm 21 \mathrm{nmol})$. The improvement of NO production by the microvascular EC by captopril and CV11974 was completely inhibited by $\mathrm{NG}^{\mathrm{G}}$-nitro-L-arginine methyl ester (L-NAME, $100 \mathrm{mmol} / \mathrm{L}$ ) (Fig 2), which suggests that NO is generated by NO synthase in these cells.

\section{Angiotensin II Concentration and ATI Receptor Expression}

We then used radioimmunoassay (SRL, Tokyo, Japan) to examine the angiotensin II concentration in the cultured medium of cardiac microvascular EC and found that there were no significant differences between the groups (control: $3.38 \pm 3.11 \mathrm{pg} / \mathrm{ml}$, captopril: $5.12 \pm 2.59 \mathrm{pg} / \mathrm{ml}$, and CV11974: $2.38 \pm 2.62 \mathrm{pg} / \mathrm{ml}$ ).

We used Western blotting to also examine the protein expression of the AT1 receptor in the cardiac microvascular EC and as shown in Fig 3, there was no difference among the 3 groups.
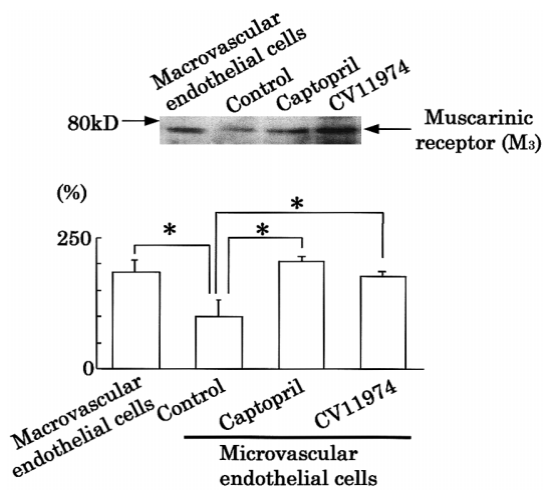

Fig 4. The level of $\mathrm{M}_{3}$ receptor in cardiac microvascular endothelial cells was significantly increased by captopril and CV11974. Data are mean \pm SD from 3 separate experiments. $* \mathrm{p}<0.01$ vs control.

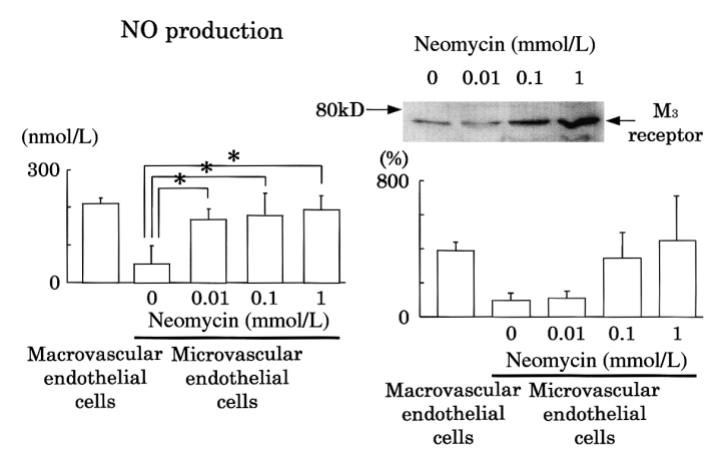

Fig 5. Effects of neomycin (phospholipase $\mathrm{C}$ inhibitor) on NO production (Left) and $\mathrm{M}_{3}$ receptor expression (Right). Data are mean \pm SD from 4 separate experiments. ${ }^{*} \mathrm{p}<0.01$ vs control.

Protein Expression of eNOS in Cardiac Microvascular EC

A number of previous studies have shown that the endothelial dysfunction in atherosclerosis is related to downregulation of eNOS 21 In the present study NO production was inhibited by L-NAME in cardiac microvascular EC (Fig 2), so we used Western blotting to examine the protein expression of eNOS in these cells, but there were no differences among the 3 groups (Fig 3).

\section{Expression of M3 Receptor and Effects of a Phospholipase C Inhibitor}

In EC, vasodilation elicited by muscarinic stimulation is mediated by release of $\mathrm{NO}$ consequent to the activation of the $\mathrm{M}_{3}$ receptor22 Therefore, we examined the levels of the $\mathrm{M} 3$ receptor protein in cardiac macrovascular and microvascular EC cultured with vehicle, captopril and CV11974. The protein level of the $\mathrm{M}_{3}$ receptor was decreased in cardiac microvascular EC given vehicle compared with the cardiac macrovascular EC (Fig 4), but was increased by the treatment with captopril and CV11974 $(\mathrm{p}<0.01)$ to the same level as the cardiac macrovascular EC. These data suggest that the upregulation of $\mathrm{M}_{3}$ receptor is related to improvement in NO production in cardiac microvascular EC by captopril and CV11974.

To examine whether the upregulation of the $\mathrm{M}_{3}$ receptor with resultant improvement of NO production was mediated by the AT1 receptor-mediated signaling pathway, we cultured cardiac microvascular EC with a phospholipase C (PLC) inhibitor, neomycin, and as shown in Fig 5, both carbachol-induced NO production and $\mathrm{M}_{3}$ protein expres- 
sion improved in a dose-dependent manner $(\mathrm{p}<0.01)$. These data suggest that the upregulation of $\mathrm{M}_{3}$ receptor by captopril and CV11974 occurs via a phospholipase C-dependent pathway.

\section{Discussion}

We report successful isolation of cardiac macrovascular and microvascular EC from adult rat hearts and have shown that cardiac microvascular EC express eNOS and generate NO in the basal condition, as has been reported in macrovascular EC, but that the NO production in response to carbachol is decreased. Treatment with captopril, CV11974, and neomycin improved NO production in cardiac microvascular EC associated with increased protein expression of the $\mathrm{M}_{3}$ receptor.

\section{Microvascular and Macrovascular Endothelial Function}

The vascular endothelium plays a pivotal role in the control of vascular tone by releasing various vasoactive substances! NO is generated from the endothelium and plays a key role in many physiological and pathological conditions including the regulation of cardiovascular function, blood pressure, flow, vascular proliferation, platelet function, etc. It has been demonstrated that endotheliumdependent vasodilation is impaired in several pathological conditions including atherosclerosis and hypertension ${ }^{23-25}$ The endothelium has a significantly heterogeneous structure and function among organs, and there are differences between macrovascular and microvascular endothelium? ${ }^{26}$ A number of studies have shown that cardiac microvascular EC play important roles in physiological and pathological conditions such as hypertrophy, ischemia and collateral development ${ }^{14,15}$ Cardiac microvascular EC release peptides and/or autacoids, which act on cardiomyocytes downstream. It has been also reported that an interaction between microvascular endothelium and cardiomyocytes is important in various pathological conditions $;^{7}$ for example, the endothelial dysfunction associated with hypertension and diabetes mellitus occurs primarily in cardiac microvessels with a diameter of less than $250 \mu \mathrm{m}$. However, systematic evaluation of cardiac microvascular endothelial function has not been rigorously performed because suitable in vitro models are not available. Ando et al reported successful isolation of cardiac microvascular EC from porcine hearts and showed lower eNOS activity compared with aortic EC ${ }^{14}$ In the present study, we compared NO production in response to carbachol between cardiac macrovascular and microvascular EC and found that carbachol-induced NO production was significantly decreased in the microvascular EC.

\section{Effects of ACE Inhibitor and AT1 Receptor Antagonist}

Carbachol-induced NO production was improved by captopril and CV11974 in the cardiac microvascular EC only. To study the mechanism of this improvement, we examined eNOS protein expression and found that the levels of eNOS did not differ among cardiac microvascular EC treated with or without captopril and CV11974. These results indicated that the decrease in carbachol-induced NO production in cardiac microvascular EC was not related to eNOS downregulation. In the present study, AT1 receptor protein expression and angiotensin II concentration were unexpectedly unchanged among the groups treated with vehicle, captopril and CV11974. We demonstrated for the first time, to our knowledge, that the protein levels of the $\mathrm{M} 3$ receptor were decreased in cardiac microvascular EC compared with macrovascular EC, but were improved by treatment with captopril, CV11974 and neomycin. Improvement in the $\mathrm{M}_{3}$ protein levels was closely related with improved NO production in response to carbachol stimulation. These results suggest that this improvement in cardiac microvascular endothelial function is related to the inhibition of the AT1 receptor/PLC pathway. Shibata et al have suggested that carbachol increases AT2 receptor mRNA in PC12 cells and they suggest that there is crosstalk between the muscarinic and AT2 receptors, and that activation of the angiotensin II/AT2 receptor increases $\mathrm{M}_{3}$ receptor protein expression 28 Although the precise mechanisms are still unknown, clinical data showing reversed endothelial dysfunction by AT1 receptor antagonism has been reported in patients with atherosclerosis 29 coronary artery disease ${ }^{30}$ and hypertension $3{ }^{31}$ Our present data indicate that increased expression of $\mathrm{M}_{3}$ receptor contributes, at least in part, to the improved endothelial function with this therapy.

\section{Study Limitations}

The passage of blood in the vessels generates hemodynamic forces, such as shear stress, and regulates the function of EC lining the intimal surface of the vasculature. Our in vitro study using cardiac microvascular EC was not performed under physiological conditions, so although our data indicate that increased expression of the $\mathrm{M}_{3}$ receptor by ACE inhibitor and AT1 receptor antagonist contributes to improved endothelial function, other mechanisms may also account for this effect. We did not clarify the mechanism of improvement of carbachol-induced NO production via PLC inhibition because neomycin has some non-selective actions and we could not measure PLC activity.

\section{Conclusion}

We report successful isolation of cardiac macrovascular and microvascular EC from adult rat hearts, and primary culture of these cells may be a useful tool for investigating the pathophysiological status of cardiac microvascular endothelial function. The present data suggest that beneficial effects of ACE inhibitor and AT1 receptor antagonist on microvascular endothelial function may be related to upregulation of $\mathrm{M}_{3}$ receptors.

\section{Acknowledgments}

This study was supported in part by a grant-in-aid for Scientific Research (No. 12770337) from the Ministry of Education, Science, Sports and Culture, Japan and grants from Kanae Foundation, the Naito Foundation and the Japan Heart Foundation Research Grant.

\section{References}

1. Griffith TM, Edwards DH, Lewis MJ, Newby AC, Henderson AH. The nature of endothelium-derived vascular relaxant factor. Nature 1984; 308: 645-647.

2. Linder L, Kiowski W, Buhler FR, Luscher TF. Indirect evidence for endothelium-derived relaxing factor in human forearm circulation in vivo: Blunted response in essential hypertension. Circulation 1990; 81: $1762-1767$.

3. Panza JA, Casino PR, Kilcoyne CM, Quyyumi AA. Role of endothelium-derived nitric oxide in the abnormal endothelium-dependent vascular relaxation of patients with essential hypertension. Circulation 1993; 87: 1468-1474.

4. Treasure CB, Vita JA, Cox DA, Fish RD, Gordon JB, Mudge GH, et al. Endothelium-dependent dilation of the coronary microvasculature is impaired in dilated cardiomyopathy. Circulation 1990; 81: $772-$ 
779 .

5. Katz SD, Biasucci L, Sabba C, Strom JA, Jondeau G, Galvao M, et al. Impaired endothelium-mediated vasodilation in the peripheral vasculature of patients with congestive heart failure. J Am Coll Cardiol 1992; 19: $918-925$.

6. Kubo SH, Rector TS, Bank AJ, Williams RE, Heifeltz SM. Endothelium-dependent vasodilation is attenuated in patients with heart failure. Circulation 1991; 84: 1589-1596.

7. Katz SD, Schwarz M, Yuen J, LeJemtel TH. Impaired acetylcholinemediated vasodilation in patients with congestive heart failure: Role of endothelium-derived vasodilating and vasoconstricting factors. Circulation 1993; 88: 55-61.

8. Kato M, Shiode N, Yamagata T, Matsuura H, Kajiyama G. Coronary segmental responses to acetylcholine and bradykinin in patients with atherosclerotic risk factor. Am J Cardiol 1997; 80: 751 - 755 .

9. Treasure CB, Manoukian SV, Klein JL, Vita JA, Nabel EG, Renwick $\mathrm{GH}$, et al. Epicardial coronary artery responses to acetylcholine are impaired in hypertensive patients. Circ Res 1992; 71: 776-781.

10. Casino PR, Kilcoyne CM, Cannon RO 3rd, Quyyumi AA, Panza JA. Impaired endothelium-dependent vascular relaxation in patients with hypercholesterolemia extends beyond the muscarinic receptor. Am J Cardiol 1995; 75: 159-176.

11. Kiowski W, Sutsch G, Schalcher C, Brunner HP, Oechslin E. Endothelial control of vascular tone in chronic heart failure. J Cardiovasc Pharmacol 1998; 32(Suppl3): S67-S73.

12. Nishida M, Carley WM, Gerritsen ME, Ellingsen O, Kelly RA, Smith TW. Isolation and characterization of human and rat cardiac microvascular endothelial cells. Am J Physiol 1993; 264: H639-H652.

13. Grafe M, Auch-Schwelk W, Graf K, Terbeek D, Hertel H, Unkelbach $\mathrm{M}$, et al. Isolation and characterization of macrovascular and microvascular endothelial cells from human hearts. Am J Physiol 1994; 267: $\mathrm{H} 2138-\mathrm{H} 2148$.

14. Ando H, Kubin T, Schaper W, Schaper J. Cardiac microvascular endothelial cells express a-smooth muscle actin and show low NOS III activity. Am J Physiol 1999; 276: H1755-H1768.

15. Balligand J, Kelly R, Smith T. Cardiac endothelium and tissue growth. Prog Cardiovasc Dis 1997; 38: 351-360.

16. Yamada K, Nabeshima T. Simultaneous measurement of nitrite and nitrate levels as indices of nitric oxide release in the cerebellum of conscious rats. J Neurochem 1997; 68: 1234-1243.

17. Takeishi Y, Ping P, Bolli R, Kirkpatrick DL, Hoit BD, Walsh RA. Transgenic overexpression of constitutively active protein kinase $\mathrm{C}$ $\epsilon$ causes concentric cardiac hypertrophy. Circ Res 2000; 86: 1218 1223.

18. Miyashita T, Takeishi Y, Takahashi H, Kato S, Kubota I, Tomoike $\mathrm{H}$. Calcineurin is involved in insulin-like growth factor-1-induced hypertrophy of cultured adult rat ventricular myocytes. Jpn Circ J
2001; 65: 815-819.

19. Golledge J, Turner RJ, Harley SL, Springall DR, Powell JT. Circumferential deformation and shear stress induce differential responses in saphenous vein endothelium exposed to arterial flow. J Clin Invest 1997; 99: 2719-2726.

20. Ali MS, Sayeski PP, Dirksen LB, Hayzer DJ, Marrero MB, Bernstein KE. Dependence on the motif YIPP for the physical association of Jak2 kinase with the intracellular carboxyl tail of the angiotensin II AT-1 receptor. J Biol Chem 1997; 272: 23382-23388.

21. Barry SO, Marcel RT, Nelson G, Victor B, Tadeusz M, Thomas FL. Reduced endothelial nitric oxide synthase expression and production in human atherosclerosis. Circulation 1998; 97: 2494-2498.

22. Ren LM, Nalane T, Chiba S. Muscarinic receptor subtypes mediating vasodilation and vasoconstriction in isolated, perfused simian coronary arteries. J Cardiovasc Pharmacol 1993; 22: 841-846.

23. Bossaller C, Habib GB, Yamamoto H, William C, Wells S, Henry PD. Impaired muscarinic endothelium-dependent relaxation and cyclic guanosine 5'-monophosphate formation in atherosclerotic human coronary artery and rabbit aorta. J Clin Invest 1987; 79: 170-174.

24. Bossaller C, Hehlert-Friedrich C, Jost S, Rafflenbeul W, Lichtlen P. Angiographic assessment of human coronary artery endothelial function by measurement of endothelium-dependent vasodilation. Eur Heart J 1989; 10(SupplF): 44-48.

25. Grossman DC, Larkin SW, Dashwood M, Davies GJ, Yacoub M, Masseri A. Atherosclerotic human coronary vessels preserve a dilator response to substance P in vivo. Br Heart J 1989; 61: 455-456.

26. Kumar S, West D, Ager A. Heterogeneity in endothelial cells from large vessels and microvessels. Differentiation 1987; 36: 57-70.

27. Ramaciotti C, Sharkey A, McClellan G, Winegrad S. Endothelial cells regulate cardiac contractility. Proc Natl Acad Sci USA 1993; 90: $4033-4036$

28. Shibata K, Ikuko K, Inoue K, Katsuragi T. Muscarinic acetylcholine receptor-mediated increase of angiotensin type 2 receptor mRNA in PC 12 cells. Neuroreport 1998; 9: 3783-3789.

29. Prasad A, Tupas-Habib T, Schenke WH, Mincemoyer R, Panza JA, Waclawin MA, et al. Acute and chronic angiotensin-1 receptor antagonism reverses endothelial dysfunction in atherosclerosis. Circulation 2000; 101: 2349-2354.

30. Mancini GB, Henry GC, Macaya C, O'Neill BJ, Pucillo AL, Carere $\mathrm{RG}$, et al. Angiotensin-converting enzyme inhibition with quinapril improves endothelial vasomotor dysfunction in patients with coronary artery disease: The TREND (Trial on Reversing Endothelial Dysfunction) Study. Circulation 1996; 94: 258-265.

31. Schiffrin EL, Park JB, Intengan HD, Touyz RM. Correction of arterial structure and endothelial dysfunction in human essential hypertension by the angiotensin receptor antagonist losartan. Circulation 2000; 101: $1653-1659$. 